\title{
Rapid modulation of electrolyte transport in Caco-2 cell monolayers by enteropathogenic Escherichia coli (EPEC) infection
}

\author{
G K Collington, I W Booth, S Knutton
}

\begin{abstract}
Background and aims-The pathophysiology of enteropathogenic Escherichia coli (EPEC) diarrhoea remains uncertain. EPEC adhere to enterocytes and transduce signals which produce a characteristic "attaching and effacing" (A/E) lesion in the brush border membrane. The present in vitro study was designed to determine whether signal transduction by EPEC also influences electrolyte transport.

Methods-Caco-2 cell monolayers were rapidly infected with wild type EPEC strain E2348/69, or the signal transduction-defective mutant 14.2.1(1), and mounted in Ussing chambers.

Results-Strain E2348/69 stimulated a rapid but transient increase in short circuit current (Isc) which coincided with A/E lesion formation; this Isc response was absent on infection with strain 14.2.1(1). While the initial rise in Isc induced by E2348/69 was partially ( $35 \%)$ dependent on chloride, the remainder possibly represents an influx of sodium and amino acid(s) across the apical membrane.

Conclusions-The study directly shows that, after initial adhesion, EPEC induce major alterations in host cell electrolyte transport. The observed Isc responses indicate a rapid modulation of electrolyte transport in Caco-2 cells by EPEC, including stimulation of chloride secretion, for which signal transduction to host cells is a prerequisite.

(Gut 1998;42:200-207)
\end{abstract}

Keywords: enteropathogenic Escherichia coli; Caco-2 cells; Ussing chambers; electrolyte transport; signal transduction

Institute of Child Health, University of Birmingham

G K Collington

I W Booth

S Knutton

Correspondence to:

Dr G K Collington, Institute of Child Health, University of Birmingham, Francis Road, Birmingham B16 8ET, UK.

Accepted for publication 5 September 1997 non-intimate attachment; (2) signal transduction to host cells leading to disruption of the brush border cytoskeleton and effacement of microvilli; (3) intimate adhesion of bacteria to the apical cell membrane and accumulation of host cell cytoskeletal elements beneath attached bacteria.

EPEC possess a large (55-70 MDa) plasmid encoding adherence factors which promote stage 1 . Stages 2 and 3 involve chromosomal genes of the locus of enterocyte effacement (LEE). ${ }^{9}$ Signal transduction to host cells requires EPEC secreted proteins (Esps); these are exported via a type III secretion system which involves genes within the LEE designated sep (for secretion of $E$ coli proteins). ${ }^{10} 11$ Signalling results in tyrosine phosphorylation of a $90 \mathrm{kDa}$ host cell protein, Hp90. ${ }^{12}$ Intimate EPEC attachment (stage 3) is mediated by intimin, a $94 \mathrm{kDa}$ outer membrane protein, binding of which to $\mathrm{Hp} 90$ promotes accretion of cytoskeletal elements beneath attached bacteria to produce the mature $\mathrm{A} / \mathrm{E}$ lesion. ${ }^{13}{ }^{14}$

An assumption has been made that loss of functional microvillous surface area associated with $\mathrm{A} / \mathrm{E}$ lesion formation leads to malabsorption and osmotic diarrhoea. A reduction in absorptive capacity has been shown in intestinal tissues using rabbit models of EPEC infection $^{15}{ }^{16}$; however, malabsorption alone would not explain the rapid onset of diarrhoea (as early as three hours) reported in experimental human infections. ${ }^{17}$ This suggests the possibility of an EPEC induced secretory process, particularly in early infection. Given that no direct effect of EPEC infection on transepithelial electrolyte transport had been shown, we undertook to investigate this possibility in vitro.

Polarised cultured human intestinal cell lines - for example, Caco-2 - grown on permeable supports and mounted into Ussing chambers can be used as in vitro models of transporting epithelia. ${ }^{18}$ EPEC bind to Caco-2 cells, transduce signals, and produce $\mathrm{A} / \mathrm{E}$ lesions identical with those seen in natural infections. ${ }^{20}$ Using a rapid infection procedure we have studied the effects of EPEC infection on the transepithelial electrical parameters and ultrastructure of Caco-2 cells, from the onset of initial adhesion. The role of EPEC signal transduction in observed responses has been investigated using an EPEC class four mutant ( $\mathrm{cfm}$ ) that is unable to secrete signalling proteins, essential for $\mathrm{A} / \mathrm{E}$ lesion formation, because of the interruption of a sep gene sequence..$^{11121}$

This study has been presented in part to the British Society of Gastroenterology. ${ }^{22}$ 
Table 1 Characteristics of EPEC strains used in this study

\begin{tabular}{|c|c|c|c|c|}
\hline \multirow[b]{2}{*}{ Strain } & \multirow[b]{2}{*}{ Origin } & \multicolumn{2}{|c|}{ EPEC characteristics } & \multirow[b]{2}{*}{ References } \\
\hline & & $\begin{array}{l}\text { Signal } \\
\text { transduction }\end{array}$ & $\begin{array}{l}\text { "Attaching } \\
\text { and effacing" } \\
\text { adhesion }\end{array}$ & \\
\hline \multicolumn{5}{|c|}{$E \operatorname{coli}(0127: \mathrm{H} 6)$} \\
\hline E2348/69 & Infant diarrhoea outbreak, UK & + & + & 12,23 \\
\hline $14.2 .1(1)$ & $\begin{array}{l}\text { Class four TnphoA insertion mutant } \\
\text { of E2348/69 }\end{array}$ & - & - & 12,21 \\
\hline
\end{tabular}

\section{Methods}

BACTERIA

Table 1 shows the origins and characteristics of the bacterial strains used in this study. Bacteria were grown routinely from frozen stocks subcultured into Mueller-Hinton broth (Oxoid Ltd, Basingstoke, Hants, UK) and incubated aerobically at $37^{\circ} \mathrm{C}$ for 18 hours. To facilitate expression of EPEC adherence factors, broth grown bacteria were subcultured (1:100 dilution) into bicarbonate buffered Dulbecco's modified Eagle's medium containing 25 $\mathrm{mmol} / 1$ glucose (DMEM; Sigma Chemical Co, Poole, Dorset, UK) and incubated in an atmosphere of $5 \% \mathrm{CO}_{2}$ in air at $37^{\circ} \mathrm{C}$ for four to five hours. ${ }^{24}$ The number of viable bacteria present in cultures was determined by plating serial dilutions of culture on to Mueller-Hinton agar, incubating aerobically at $37^{\circ} \mathrm{C}$, and counting resultant colony forming units (CFU).

Supernatants of DMEM grown cultures were obtained by centrifugation at $10000 \mathrm{~g}$ for $30 \mathrm{~min}$, and sterilised by filtration through a $0.45 \mu \mathrm{m}$ filter (Millipore Ltd, Watford, Herts, $\mathrm{UK})$.

\section{CELL CULTURE}

Caco-2 cells were grown in DMEM supplemented with $1 \%$ non-essential amino acids, 2 $\mathrm{mmol} / 1 \mathrm{~L}$-glutamine, and $10 \%$ fetal calf serum. Cells were maintained in a humidified atmosphere of $5 \% \mathrm{CO}_{2}$ in air at $37^{\circ} \mathrm{C}$. Single-cell suspensions were obtained from confluent serial cultures by incubation with $0.25 \%$ trypsin and $0.02 \%$ EDTA in $\mathrm{Ca}^{2+}$ and $\mathrm{Mg}^{2+}$-free Hanks balanced salt solution. Caco- 2 cells were seeded at a density of $5 \times 10^{4}$ cells $/ \mathrm{cm}^{2}$ on to Transwell polycarbonate microporous cell culture inserts $(24.5 \mathrm{~mm}$ diameter, $0.4 \mu \mathrm{m}$ pore; Costar Ltd, High Wycombe, Bucks, UK); monolayers were used a minimum of 21 days after seeding, by which time transepithelial electrical resistance (TEER) was stable $\left(\sim 150 \Omega . \mathrm{cm}^{2}\right)$ and cells exhibited a morphologically distinct apical brush border. All cell culture media, supplements, and reagents were purchased from Sigma.

INFECTION OF CACO-2 MONOLAYERS

Before infection with EPEC, Caco-2 monolayers growing on culture inserts were placed into prewarmed $\left(37^{\circ} \mathrm{C}\right)$ DMEM without fetal calf serum and returned to routine incubation conditions for one hour. For rapid infection of monolayers, the culture insert was placed into a $30 \mathrm{~mm}$ diameter Petri dish and the DMEM bathing the apical cell surface was replaced with $1 \mathrm{ml}$ DMEM grown bacterial culture (about $\left.10^{8}-10^{9} \mathrm{CFU}\right)$; initial attachment of adherent bacteria to Caco-2 monolayers was facilitated by centrifugation on to the apical cell surface at 500 $g$ for $4 \mathrm{~min}$. After centrifugation, monolayers were rinsed in DMEM to remove non-adherent bacteria. Uninfected Caco-2 monolayers were subjected to all procedures involved in infection except exposure to bacteria.

MEASUREMENT OF TRANSEPITHELIAL ELECTRICAL PARAMETERS OF CaCO-2 MONOLAYERS

For measurement of transepithelial electrical parameters, a culture insert with Caco- 2 monolayer in situ was mounted between two Perspex half-chambers of a modified Ussing chamber. Each half-chamber was circulated continuously with $15 \mathrm{ml}$ bathing solution (gassed with $5 \% \mathrm{CO}_{2} / 95 \% \mathrm{O}_{2}$ ) passing through a waterjacketed reservoir at $37^{\circ} \mathrm{C}$. The exposed surface area of the monolayer was $3.8 \mathrm{~cm}^{2}$. Monolayers were studied under short circuited conditions. The short circuit current (Isc) was passed through $3 \mathrm{~mol} / 1 \mathrm{KCl} /$ agar bridges in series with $\mathrm{Ag} / \mathrm{AgCl}$ electrodes connected to an automatic voltage clamp (WPI Inc, New Haven, CT, USA) which compensated for the resistances of the bathing solution and the culture insert. Transepithelial potential difference was detected using calomel electrodes in series with $3 \mathrm{~mol} / 1 \mathrm{KCl} /$ agar bridges. Voltage pulses were used for determining TEER $\left(\Omega . \mathrm{cm}^{2}\right)$ according to Ohm's law.

The bathing solution used in Ussing chambers was DMEM (prepared with the following composition (mmol/l): $\mathrm{NaCl} 104 ; \mathrm{KCl} \mathrm{5.4;}$

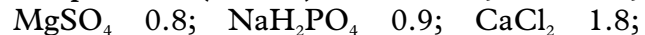
$\mathrm{NaHCO}_{3} 44$; D-glucose 25) containing 1:25 dilution of Eagle's minimum essential medium $(\mathrm{MEM})(\times 100)$ vitamin solution (M6895, Sigma) and 1:25 dilution of MEM $(\times 50)$ amino acid solution (M7020, Sigma; L-amino acid composition ( $\mathrm{mmol} / \mathrm{l})$ : arginine 30, cystine 5 , histidine 10 , isoleucine 20 , leucine 20 , lysine 20 , methionine 5 , phenylalanine 10 , threonine 20 , tryptophan 2.5 , tyrosine 10 , valine 20 ). A nominally $\mathrm{Cl}^{-}$-free bathing solution was prepared by substituting $\mathrm{SO}_{4}^{2-}$ for $\mathrm{Cl}^{-}$. In nominally $\mathrm{Na}^{+}$-free bathing solution, $\mathrm{NaCl}, \mathrm{NaH}_{2} \mathrm{PO}_{4}$ and $\mathrm{NaHCO}_{3}$ were replaced by choline chloride, $\mathrm{KH}_{2} \mathrm{PO}_{4}$ and $\mathrm{KHCO}_{3}$ respectively. Amino acid- and glucose-free bathing solutions were prepared by omission of the respective solutes. Osmolarity in all depleted media was maintained by addition of mannitol. Unless otherwise specified, all materials used in the preparation of bathing solutions were AnalaR grade (Merck Ltd, Poole, Dorset, UK). Additional reagents (amphotericin B and dibutyryl cyclicAMP (DbcAMP)) were purchased from Sigma.

BACTERIAL ADHESION

The level of adhesion of bacterial strains to Caco- 2 cells was assessed after fixation in $70 \%$ methanol. Fixed preparations were Giemsa stained, and the proportion of cells with adherent bacterial colonies was determined by light microscopy.

For transmission electron microscopy, infected Caco- 2 monolayers on culture inserts were fixed in $3 \%$ phosphate buffered $(0.1$ 


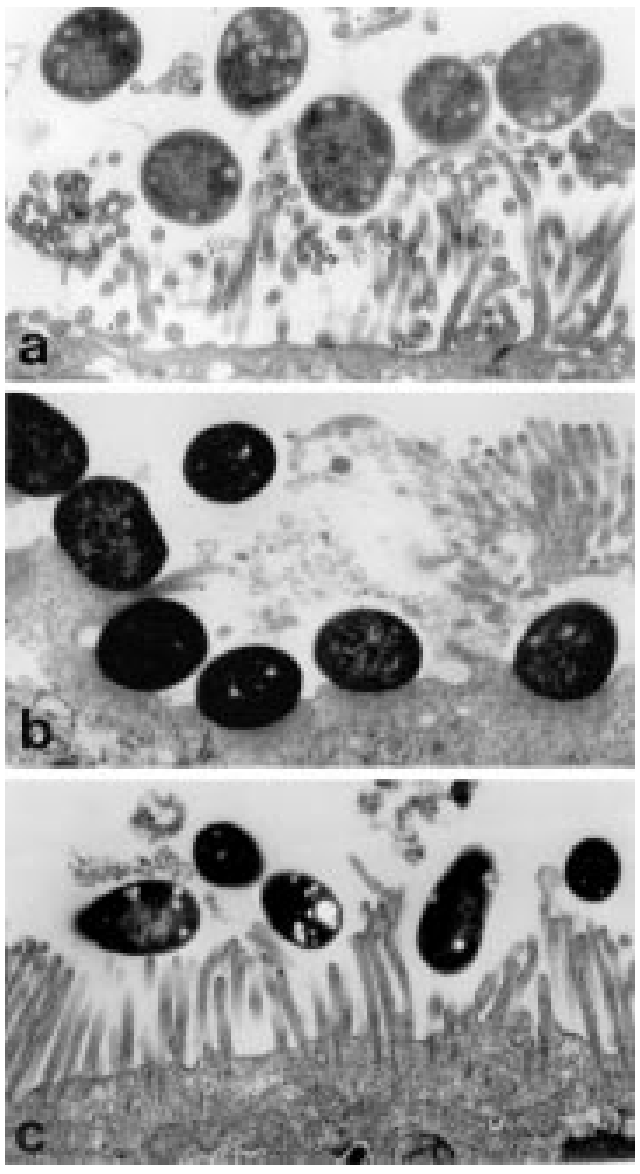

Figure 1 Transmission electron micrographs of EPEC adhesion to Caco-2 monolayers. On initial infection, both wild type strain E2348/69 (a) and cfm strain 14.2.1(1) adhered to intact brush border microvilli. After 15 minutes, E23438/69 were intimately attached to the apical

membrane devoid of microvilli (b); however, even after 60 minutes, 14.2.1(1) did not intimately adhere to host cells (c). Original magnification: $\times 17500$.

mol/l, pH 7.4) glutaraldehyde. Segments of fixed monolayer, with supporting polycarbonate membrane, were post-fixed in $1 \%$ buffered osmium tetroxide, block stained in aqueous $1 \%$ uranyl acetate and embedded in Epon. Ultrathin sections were stained with uranyl and lead salts and examined using a Jeol 1200 EX electron microscope.

STATISTICAL ANALYSES

Results are presented as mean (SEM). The data were analysed using Student's $t$ test and $\mathrm{p}<0.05$ was considered statistically significant.

\section{Results}

EPEC ADHESION TO CaCO-2 MONOLAYERS Caco-2 monolayers were infected with either the wild type EPEC strain E2348/69 or the $c f m$ 14.2.1(1); the rapid infection method used produced synchronous initial attachment of bacteria to at least $75 \%$ of the cells in a monolayer.

To assess development of $\mathrm{A} / \mathrm{E}$ lesions after rapid EPEC infection of Caco-2 cells, electron microscopy of monolayers was performed immediately after initial attachment of bacteria, and after 15, 30, and 60 minutes of subsequent incubation in Ussing chambers. At the onset of infection, both E2348/69 and
14.2.1(1) were seen attached to intact brush border microvilli (fig 1a illustrates initial adhesion of E2348/69). For strain E2348/69, characteristic $\mathrm{A} / \mathrm{E}$ lesions were apparent by $15 \mathrm{~min}$ utes with bacteria intimately attached to the apical membrane devoid of microvilli (fig 1b); the failure of strain 14.2.1(1) to generate lesions (fig 1c), even after 60 minutes of infection, confirmed the lack of an $\mathrm{A} / \mathrm{E}$ phenotype for this signal transduction-defective mutant.

EFFECT OF EPEC INFECTION ON TRANSEPITHELIAL ELECTRICAL PARAMETERS OF CaCO-2 MONOLAYERS

Recordings of Caco-2 transepithelial electrical parameters were begun immediately after mounting monolayers into the Ussing chamber. Stable TEER values were obtained in uninfected monolayers within five minutes of mounting. Whereas uninfected Caco- 2 monolayers maintained a constant Isc throughout the 60 minute study period, infection with EPEC strain E2348/69 induced a rapid increase in Isc (fig 2A) which reached a peak value after 10.5 minutes and which, despite subsequent decay, was still significantly higher than that in uninfected cells after 60 minutes. The distinctive Isc response induced by our wild type EPEC strain was not apparent when Caco-2 monolayers were infected with strain 14.2.1(1); infection with the signal transduction-defective mutant was associated with only a small sustained increase in Isc (fig $2 \mathrm{a}$ ).

The peak Isc induced by E2348/69 was not associated with any significant change in the TEER of Caco-2 monolayers (TEER at 10 min: uninfected $v \mathrm{E} 2348 / 69$ infected; 152 (8) $v$ 143 (6) $\left.\Omega \cdot \mathrm{cm}^{2} ; \mathrm{n}=9, \mathrm{p}>0.05\right)$. However, whereas the TEER of uninfected monolayers subsequently remained stable, E2348/69 infection caused a $20 \%$ reduction during the following 50 minutes, increasing to $40 \%$ by four hours (fig $2 b$ ). This observation confirms previous reports of a detrimental effect of EPEC infection on TEER of cultured epithelial cell monolayers. ${ }^{25}{ }^{26}$ In contrast, infection with strain 14.2.1(1) did not adversely affect monolayer TEER (fig $2 b$ ).

The influence of EPEC culture supernatant on transepithelial electrical parameters was examined by replacing bilaterally the Ussing chamber bathing solution with a sterile filtrate of DMEM grown E2348/69; no changes in Isc or TEER of uninfected Caco-2 cells were observed over the next 60 minutes (data not shown).

CHLORIDE DEPENDENCE OF E2348/69 INDUCED ISC RESPONSE

To examine the $\mathrm{Cl}^{-}$dependence of the E2348/69 stimulated Isc response, nominally $\mathrm{Cl}^{-}$-free bathing solution was used in the Ussing chambers; treatment of Caco-2 monolayers and bacteria before mounting into chambers was otherwise unchanged. Under $\mathrm{Cl}^{-}$-free conditions the initial Isc increase caused by E2348/69 was reduced by up to $35 \%$ (fig 3), and the peak Isc was delayed by three minutes and significantly decreased from 22.3 (1.4) to 16.9 (1.3) $\mu \mathrm{A} / \mathrm{cm}^{2} \quad(\mathrm{n}=9, \mathrm{p}<0.05)$. The 


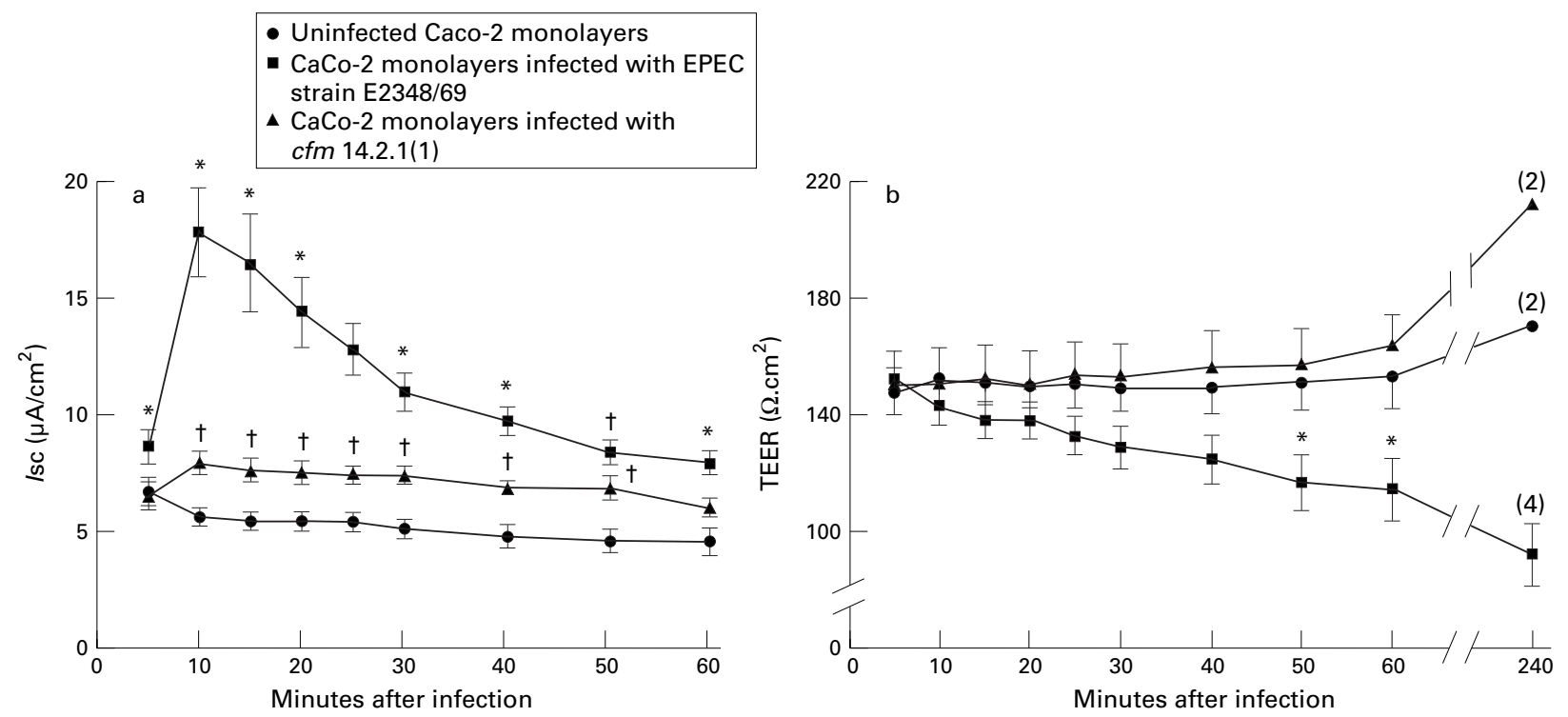

Figure 2 (a) Short circuit current (Isc; $\mu \mathrm{A} / \mathrm{cm}^{2}$ ) and (b) transepithelial electrical resistance (TEER; $\Omega . \mathrm{cm}^{2}$ ) in uninfected Caco-2 monolayers, and those infected with EPEC strain E2348/69 or cfm 14.2.1(1). Each point represents the mean (SEM) from nine monolayers, unless otherwise indicated in parentheses. ${ }^{*} p<0.05 v$ uninfected or 14.2.1(1) infected monolayers; $t p<0.05 v$ uninfected monolayers only.

absence of $\mathrm{Cl}^{-}$did not affect the Isc of uninfected Caco-2 monolayers (fig 3), the TEER of uninfected or E2348/69 infected monolayers, or the fall in TEER associated with E2348/69 infection (data not shown).

The role of $\mathrm{Cl}^{-}$in EPEC induced Isc was further studied by examining the sensitivity of uninfected and E2348/69 infected Caco-2 monolayers to the cyclic AMP derivative DbcAMP. Apical application of DbcAMP (1 $\mathrm{mmol} / \mathrm{l}$ ) to uninfected Caco-2 monolayers stimulated a maximum Isc increase of $6.7(0.9)$ $\mu \mathrm{A} / \mathrm{cm}^{2}(\mathrm{n}=5, \mathrm{p}<0.05)$ within two minutes; Isc fell within six minutes of peak response to a plateau of $2.4(0.2) \mu \mathrm{A} / \mathrm{cm}^{2}(\mathrm{n}=5, \mathrm{p}<0.05)$ which was sustained. This response, which was

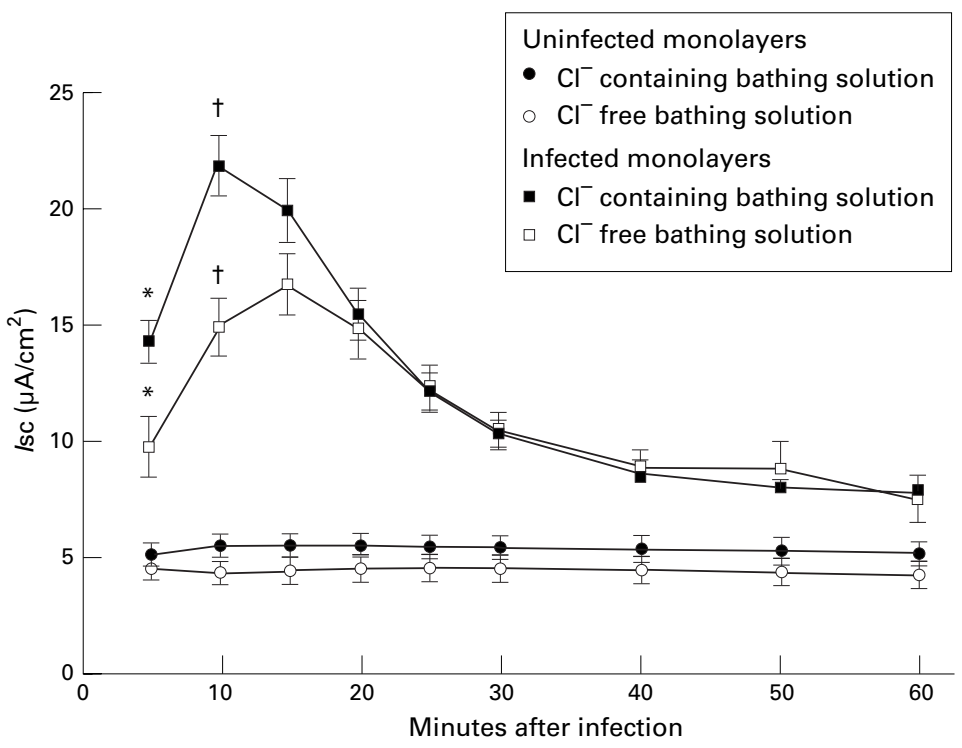

Figure $3 \mathrm{Cl}^{-}$dependence of short circuit current $\left(\mathrm{Isc} ; \mu \mathrm{A} / \mathrm{cm}^{2}\right)$ in uninfected Caco-2 monolayers and those infected with EPEC strain E2348/69. The Isc of uninfected monolayers did not differ significantly between $\mathrm{Cl}^{-}$-inclusive and $\mathrm{Cl}^{-}$-free bathing solutions; each point represents the mean (SEM) of seven monolayers. The rapid increase in Isc induced by E2348/69 in $\mathrm{Cl}^{-}$-inclusive bathing solution was significantly reduced in $\mathrm{Cl}^{-}$-free solution; each point represents mean Isc (SEM) from nine monolayers. ${ }^{\star} p<0.05 v$ uninfected or 14.2.1(1) infected monolayers; $t p<0.05 v$ uninfected monolayers. dependent on the presence of $\mathrm{Cl}^{-}$in bathing solutions, is characteristic of DbcAMP induced Isc in Caco-2 cells and indicative of electrogenic $\mathrm{Cl}^{-}$secretion. ${ }^{27}$ However, apical exposure of E2348/69 infected Caco-2 monolayers to $1 \mathrm{mmol} / 1 \mathrm{DbcAMP}$, applied five or 40 minutes after the initial infection, did not further enhance the EPEC stimulated increase in Isc (data not shown).

ROLE OF SODIUM IN E2348/69 INDUCED ISC RESPONSE

Bilateral removal of $\mathrm{Na}^{+}$from the Ussing chamber bathing solution abolished both the Isc of uninfected Caco-2 monolayers and the E2348/69 induced Isc response. In addition, the absence of $\mathrm{Na}^{+}$increased TEER of both uninfected and E2348/69 infected monolayers (TEER at 10 min: uninfected $+\mathrm{Na}^{+} v-\mathrm{Na}^{+}$; 140 (9) v 253 (57) $\Omega . \mathrm{cm}^{2} ; \mathrm{n}=5, \mathrm{p}>0.05$. E2348/69 infected $+\mathrm{Na}^{+} v-\mathrm{Na}^{+} ; 118(9) v 206$ (26) $\left.\Omega . \mathrm{cm}^{2} ; \mathrm{n}=8, \mathrm{p}<0.05\right)$. The $\mathrm{Na}^{+}$dependence of basal electrical polarity in Caco- 2 cells $^{28}$ precluded any meaningful study under $\mathrm{Na}^{+}-$ free conditions. Therefore, the contribution of $\mathrm{Na}^{+}$to EPEC induced Isc was assessed by comparing the sensitivity of uninfected and E2348/69 infected Caco-2 monolayers to application of the $\mathrm{Na}^{+}$ionophore amphotericin B $(10 \mu \mathrm{g} / \mathrm{ml}$ added to the apical bathing solution five minutes after monolayers were mounted into Ussing chambers). In uninfected monolayers, amphotericin B stimulated a progressive increase in Isc which reached a peak at 25 minutes $\left(27.2(1.3) \mu \mathrm{A} / \mathrm{cm}^{2} ; \mathrm{n}=3\right)$ (data not shown). In E2348/69 infected cells exposed to amphotericin $\mathrm{B}$, Isc increased rapidly to a peak value which, although delayed from 10 to 15 minutes, was not significantly different from that caused by infection alone (26.5 (1.9) v $23.7(2.1) \mu \mathrm{A} / \mathrm{cm}^{2} ; \mathrm{n}=3$, $\mathrm{p}>0.05)$; both of these peak Isc responses were similar in magnitude to that induced by amphotericin B in uninfected monolayers. 


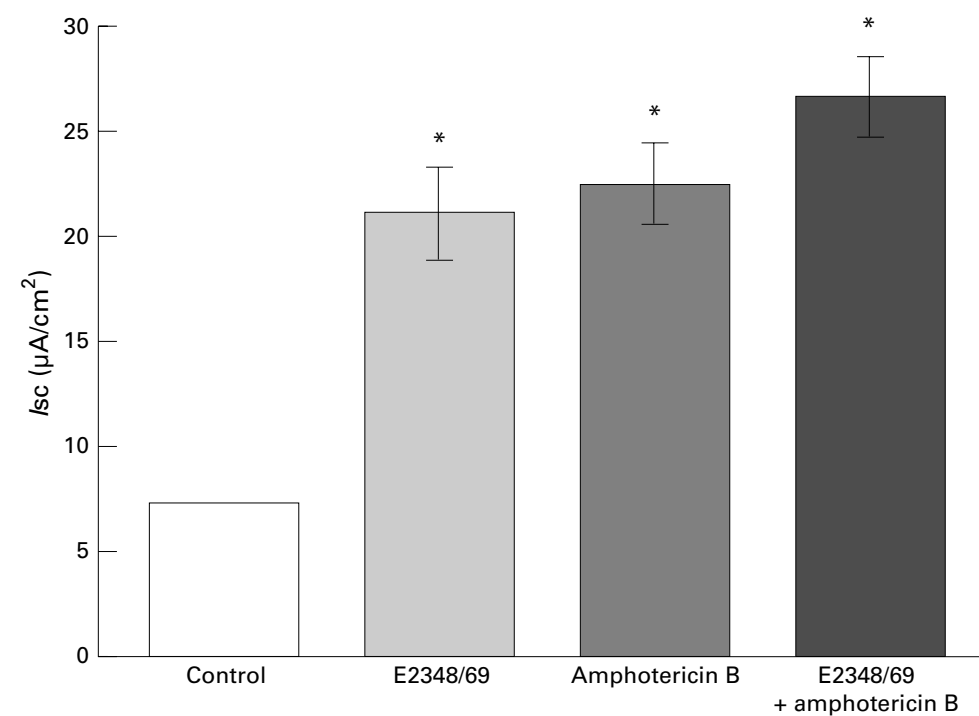

Figure 4 Effect of amphotericin $B(10 \mu \mathrm{g} / \mathrm{ml}$ apical application) on short circuit current (Isc; $\mu \mathrm{A} / \mathrm{cm}^{2}$ ) in uninfected Caco-2 monolayers and those infected with EPEC strain E2348/69. Values presented were determined 15 minutes after initial infection. Although E2348/69 infection or amphotericin B treatment induced increases in Isc, these effects were not cumulative. Each bar represents the mean (SEM) from three monolayers. ${ }^{\star} p<0.05 v$ control (uninfected and untreated) monolayers.

Moreover, no cumulative effect of E2348/69 infection and amphotericin B treatment was apparent during the initial increase in Isc (fig 4): after 15 minutes of study, the Isc increases induced by E2348/69 infection and amphotericin B treatment, respectively, were 13.6 (2.2) and $15.0(1.9) \mu \mathrm{A} / \mathrm{cm}^{2}(\Delta I \mathrm{sc}$ above uninfected/ untreated monolayers; $\mathrm{n}=3, \mathrm{p}<0.05)$; however, these responses were not additive: the increase in Isc induced by coincident E2348/69 infection and amphotericin $\mathrm{B}$ treatment was only $19.1(1.9) \mu \mathrm{A} / \mathrm{cm}^{2}(\Delta I \mathrm{sc}$ at $15 \mathrm{~min} ; \mathrm{n}=3$, $\mathrm{p}>0.05 v \mathrm{E} 2348 / 69$ infected or amphotericin B treated monolayers).

Irrespective of infection or amphotericin B treatment, TEER of Caco-2 monolayers was similar after 10 minutes of study. Subsequently, TEER in uninfected monolayers not exposed to amphotericin B was sustained (data not shown). In contrast, infection with E2348/69 or exposure to amphotericin B led to a progressive and similar fall in TEER, so that by 40 minutes TEER values were only 83 (6) and $88(1) \%(\mathrm{n}=3)$, respectively, of corresponding resistances at 10 minutes. Together, E2348/69 infection and amphotericin B treatment had an additive detrimental effect on TEER of monolayers, which by 40 minutes was reduced to 58 (4) $\%$ of that at 10 minutes $(n=3, p<0.05 v$ uninfected or E2348/69 infected monolayers).

In additional Ussing chamber studies, bathing solutions devoid of glucose or amino acids were used to explore the potential contribution of electrogenic $\mathrm{Na}^{+} /$solute cotransport to generation of the Isc induced by E2348/69. The basal electrical parameters of uninfected Caco-2 monolayers were unaffected by the absence of glucose or amino acids. The glucose-free condition did not alter the Isc response stimulated by E2348/69 or the fall in TEER associated with infection (data not shown). However, the absence of amino acids caused a dramatic reduction in the E2348/69 induced Isc response, including a $\sim 44 \%$ fall in the initial Isc increase (fig 5a). During 60 minutes of E2348/69 infection in the presence of amino acids, TEER of Caco-2 monolayers fell to $76(5) \%$ of that at 10 minutes $(n=5, p<0.05$ $v$ uninfected monolayers); however, there was no significant loss of TEER associated with

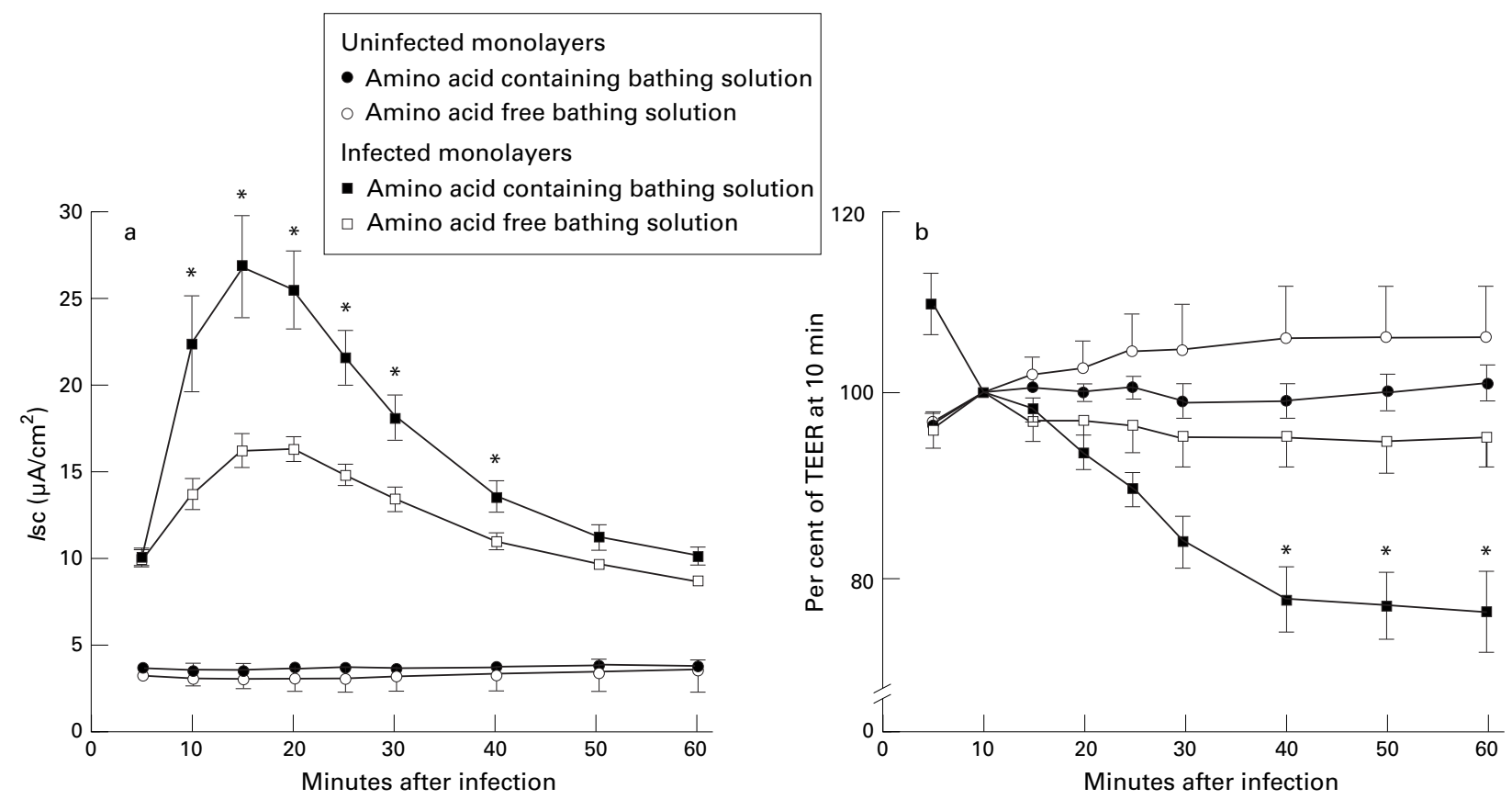

Figure 5 Amino acid dependence of (a) short circuit current (Isc; $\mu \mathrm{A} / \mathrm{cm}^{2}$ ) and (b) change in transepithelial electrical resistance (TEER; expressed as \% of TEER at 10 minutes) in uninfected Caco-2 monolayers and those infected with EPEC strain E2348/69. The Isc of uninfected monolayers did not differ significantly between amino acid-inclusive and amino acid-free bathing solutions; each point represents the mean (SEM) from eight monolayers. The rapid and sustained increase in Isc induced by E2348/69 in amino acid-inclusive bathing solution was significantly reduced in amino acid-free solution; each point represents the mean (SEM) from five monolayers. Loss of TEER associated with E2348/69 infection did not occur under amino acid-free conditions. ${ }^{\star} p<0.05 v$ infected monolayers in amino acid-free bathing solution. 
E2348/69 infection under amino acid-free conditions (fig $5 b$ ).

\section{Discussion}

Using an infection method that produces rapid synchronous attachment of EPEC to Caco-2 cells, this study directly shows that, after initial adhesion, EPEC induce major alterations in host cell electrolyte transport. Furthermore, EPEC signal transduction to host cells is an absolute prerequisite for such changes in electrolyte transport.

Cells of the human intestinal line Caco-2 form a confluent polarised monolayer in culture and undergo spontaneous enterocytic differentiation. ${ }^{28-30}$ In particular, they possess a well developed brush border membrane and a number of the polarised transport systems are present in mature small intestinal enterocytes - for example, $\mathrm{Na}^{+}$-dependent solute cotransporters. ${ }^{28}$ 31-33 They also display electrogenic secretion of $\mathrm{Cl}^{-}{ }^{27}$ Moreover, Caco-2 cells respond to EPEC infection with an $\mathrm{A} / \mathrm{E}$ lesion that is ultrastructurally and biochemically identical with that seen in native small intestinal enterocytes. ${ }^{120}$ These characteristics led us to conclude that Caco-2 cell monolayers constitute a useful model epithelium in which to study the pathophysiology of EPEC infection.

Growth of EPEC in DMEM, which stimulates expression of adherence factors, ${ }^{24}$ facilitated rapid synchronous attachment of bacteria to Caco-2 cells once they were brought into contact. This infection technique synchronises the effect of EPEC on host cells, so optimising the generation of Isc, and allowed examination of Isc before development of $\mathrm{A} / \mathrm{E}$ adhesion or any significant reduction in TEER.

The most striking electrical response to infection of Caco-2 cells with EPEC strain E2348/69 was a rapid 3-fold increase in Isc which peaked about 10 minutes after infection and subsequently decayed toward basal levels. The initial Isc increase was not associated with any reduction in TEER, although infected cells exhibited a later fall. The transient nature of the initial Isc increase cannot be explained by this TEER loss; the decay in Isc after the peak of response was well established before any significant reduction in TEER was observed. However, if the initial rise in Isc represents increased activity of a specific ion channel or electrogenic transport system in the apical membrane, the transient nature of the peak response may well reflect EPEC induced loss of functional brush border membrane which occurs during $\mathrm{A} / \mathrm{E}$ lesion formation. ${ }^{67}$

The coincidence of E2348/69 induced A/E lesion formation and initial Isc increase implicated EPEC signal transduction in the rapid modulation of Caco-2 electrolyte transport, and such a role was confirmed by the failure of the $c f m$ strain $14.2 .1(1)$ to stimulate the distinctive Isc response induced by the wild type. Recent studies have established that EPEC transduce signal to host cells by secreting specific proteins (Esps), encoded within the LEE, the export of which is dependent on sep genes. ${ }^{10}{ }^{11}$ These proteins are not secreted by the signal transduction-defective mutant 14.2.1(1) ${ }^{1011}$ and it may therefore be supposed that they are not only essential for $\mathrm{A} / \mathrm{E}$ lesion formation, but also have a role in modulation of host cell electrolyte transport. This assumption is supported by a recent study which showed a reduction in the resting membrane potential of cultured epithelial cells, determined by whole cell current clamping, during EPEC infection which was dependent on signal transduction to host cells. ${ }^{34}$

Subsequent $\mathrm{Cl}^{-}$substitution experiments indicated that at least one third of the initial Isc increase induced by strain E2348/69 was $\mathrm{Cl}^{-}$-dependent, consistent with stimulation of $\mathrm{Cl}^{-}$secretion by EPEC. The apical $\mathrm{Cl}^{-}$ conductance of Caco-2 cells is reputedly sensitive to cyclic nucleotides and calcium ${ }^{27}{ }^{35-37}$; however, there is some inconsistency in reported responses to these second messengers which may reflect differences in the maturity of the cells studied. ${ }^{36}$ In our experimental system, application of the calcium ionophore A23187 does not affect Isc of Caco-2 cells (G K Collington, I W Booth and S Knutton, unpublished observation), yet DbcAMP stimulated a characteristic Isc increase. ${ }^{27}$ Interestingly, the $\mathrm{Cl}^{-}$-dependent component of E238/69 induced Isc was similar in magnitude to the initial increase in $I \mathrm{sc}$ stimulated by $1 \mathrm{mmol} / 1$ DbcAMP, and infected Caco-2 monolayers were insensitive to the application of DbcAMP. Unfortunately, both the $\mathrm{Cl}^{-}$-dependent Isc increase induced by E2348/69 and the optimum Isc stimulated by DbcAMP were of relatively short duration, and these observations most probably reflect the limited capacity of Caco-2 cells to sustain the secretion of $\mathrm{Cl}^{-}{ }^{27} \mathrm{As}$ Caco-2 monolayers provide a poor model for the study of $\mathrm{Cl}^{-}$secretion, further in vitro evaluation of this aspect of EPEC pathogenesis would be better undertaken in an alternative intestinal cell line-for example, T84 or HT-29-which possesses greater capacity for the sustained secretion of $\mathrm{Cl}^{-} .^{18}{ }^{19}$

Although Caco-2 monolayers are not ideal for studying the secretion of $\mathrm{Cl}^{-}$, they do constitute a useful model epithelium for the study of $\mathrm{Na}^{+}$conductance. The basal electrical polarity of Caco-2 monolayers is entirely dependent on $\mathrm{Na}^{+}$, and cells maintain a high electrochemical gradient for this ion across their apical membrane. ${ }^{28}$ In the present study, apical exposure of uninfected Caco- 2 monolayers to the $\mathrm{Na}^{+}$ionophore amphotericin $\mathrm{B}$ induced a peak Isc increase similar in magnitude to that caused by EPEC infection. Furthermore, the failure of coincident amphotericin B application to enhance the initial Isc increase induced by EPEC infection suggests that the latter represents a $\mathrm{Na}^{+}$influx limited by the electrochemical gradient for this ion. As Caco- 2 cells do not possess amiloride-sensitive apical $\mathrm{Na}^{+}$conductance, ${ }^{28}$ it is unlikely that EPEC induced an influx of this ion by activation of specific channels. However, several $\mathrm{Na}^{+}$-dependent cotransporters have been identified in the Caco- 2 apical membrane, and the bathing solution contained a number of possible substrates for electrogenic $\mathrm{Na}^{+}$ 
absorption including glucose $\mathrm{e}^{31}$ and amino acids. $^{28} 32$ In solute substitution experiments, the omission of glucose had no effect on the EPEC induced Isc; however, the response was highly dependent on the presence of amino acids. The precise subject(s) of this dependence and the mechanism of enhancement remain to be identified.

The adverse effect of EPEC infection on TEER of cultured cell monolayers was originally attributed to disruption of a transcellular pathway associated with intimate $\mathrm{A} / \mathrm{E}$ lesion formation. ${ }^{25}$ However, more recent evidence has shown that EPEC cause an increase in paracellular permeability, a defect attributed to disruption of the intercellular tight junctions. ${ }^{26}$ Studies in intestinal epithelia have shown that a reduction in junctional integrity may be triggered by the activation of $\mathrm{Na}^{+} /$solute cotransporters. ${ }^{38}{ }^{39}$ Correspondingly, during 60 minutes of EPEC infection we observed a reduction in TEER of Caco-2 monolayers which was abolished by omission of amino acids from the bathing solution. Furthermore, it became apparent during the course of our studies that the percentage of TEER lost between 10 and 60 minutes of EPEC infection increased with the magnitude of peak Isc stimulated (Pearson $r=0.45, \mathrm{p}<0.05 ; \mathrm{n}=22$ ). Although stimulation of absorption appears an unlikely trait for diarrhoeagenic bacteria, activation of $\mathrm{Na}^{+} /$solute cotransport may contribute to EPEC pathogenesis by enhancing the detrimental effect of infection on tight junctional integrity.

In summary, the cause of diarrhoea during EPEC infection is considerably more complex than a loss of absorptive area consequent on $\mathrm{A} / \mathrm{E}$ lesion formation. The data presented indicate that, after initial attachment, EPEC rapidly modulate host cell electrolyte transport. Most significantly, these changes are entirely dependent on EPEC signal transduction to host cells. In addition to stimulation of $\mathrm{Cl}^{-}$secretion, which would contribute to diarrhoea during infection, EPEC possibly facilitate an influx of $\mathrm{Na}^{+}$and amino $\operatorname{acid}(\mathrm{s})$ into host cells; however, the pathophysiological significance of this effect remains unclear.

The authors thank Professor J-F Desjeux (INSERM, U290, Paris, France) for the design of the modified Ussing chamber and Dr Michael S Donnenberg (Division of Infectious Diseases, and Dr Michael S Donnenberg (Division of Infectious Diseases, University of Maryland School of Medicine, Baltimore, MD,
USA) for provision of EPEC strain 14.2.1(1). This work was supported by a grant from the Wellcome Trust (to SK).

1 Robins-Browne RM. Traditional enteropathogenic Escherichia coli of infantile diarrhea. Rev Infect Dis 1987;9:28-53.

2 Echeverria P, Orskov F, Orskov I, et al. Attaching and effacing enteropathogenic Escherichia coli as a cause of infantile diarrhea in Bangkok. F Infect Dis 1991;164:550-4.

3 Robins-Browne RM, Levine MM, Rowe B, Gabriel EM Failure to detect conventional enterotoxins in classical
enteropathogenic (serotyped) Escherichia coli strains of proven pathogenicity. Infect Immun 1982;38:798-801.

4 Long-Krug SA, Weikel CS, Tiemens KT, et al. Does enteropathogenic Escherichia coli produce heat-labile enterotoxin, heat-stable enterotoxins a or b, or cholera toxin A subunits? Infect Immun 1984;46:612-14.

5 Law D, Wilkie KM, Freeman R. Examination of enteropathogenic Escherichia coli for an adenyl cyclase stimulatopathogenic Escherichia coli for an adenyl cycl
ing factor. $\mathcal{F}$ Med Microbiol 1987;23:335-8.

6 Ulshen MH, Rollo JL. Pathogenesis of Escherichia coli gastroenteritis in man: another mechanism. $N$ Engl f Med 1980;302:99-101.
7 Rothbaum R, McAdams AJ, Gianella R, Partin JC. A clinopathological study of enterocyte-adherent Escherichia coli: a cause of protracted diarrhea in infants. Gastroenterolcoli: a cause of protracte

ogy 1982;83:441-54.
8 Donnenberg MS, Kaper JB. Minireview: enteropathogenic Escherichia coli. Infect Immun 1992;60:3953-61.

9 McDaniel TK, Jarvis KG, Donnenberg MS, Kaper JB. A genetic locus of enterocyte effacement conserved among diverse enterobacterial pathogens. Proc Natl Acad Sci USA 1995;92:1664-8.

10 Kenny B, Finlay BB. Protein secretion by enteropathogenic Escherichia coli is essential for transducing signals to epithelial cells. Proc Natl Acad Sci USA 1995;92:7991-5.

11 Jarvis KG, Girón JA, Jerse AE, et al. Enteropathogenic Escherichia coli contains a putative type III secretion system necessary for the export of proteins involved in attaching and effacing lesion formation. Proc Natl Acad Sci USA 1995;92:7996-8000.

12 Rosenshine I, Donnenberg MS, Kaper JB, Finlay BB. Signal transduction between enteropathogenic Escherichia coli (EPEC) and epithelial cells: EPEC induces tyrosine phosphorylation of host cell proteins to initiate cytoskeletal rearrangement and bacterial uptake. EMBO $\mathcal{f} 1992 ; 11$ : 3551-60

13 Jerse AE, Kaper JB. The eae gene of enteropathogenic Escherichia coli encodes a 94-kilodalton membrane protein, the expression of which is influenced by the EAF plasmid. Infect Immun 1991;59:4302-9.

14 Rosenshine I, Ruschkowski S, Finlay BB. Expression of attaching/effacing activity by enteropathogenic Escherichia coli depends on growth phase, temperature and protein synthesis upon contact with epithelial cells. Infect Immun 1996;64:966-73.

15 Tai Y-H, Gage TP, McQueen C, Formal SB, Boedeker EC. Electrolyte transport in rabbit cecum. I. Effect of RDEC-1 Electrolyte transport in rabbit cecum. I. Effect

16 Nath SK, Dechelotte P, Darmaun D, et al. $\left[{ }^{15} \mathrm{~N}\right]-$ and $\left[{ }^{14} \mathrm{C}\right]-$ glutamine fluxes across rabbit ileum in experimental bacterial diarrhea. Am f Physiol 1992;262:G312-18.

17 Donnenberg MS, Tacket CO, James SP, et al. Role of the eaeA gene in experimental enteropathogenic Escherichia coli infection. $\mathcal{F}$ Clin Invest 1993;92:1412-17.

8 Zweibaum A, Laburthe M, Grasset E, Louvard D. Use of cultured epithelial cell lines in studies of intestinal cell differentiation and function. In: Field M, Frizzell RA, eds. Handbook of physiology. The gastrointestinal system IV. Bethesda, MD: American Physiological Society, 1988:22355.

19 Nath SK, Desjeux J-F. Human intestinal cell lines as in vitro tools for electrolyte transport studies with relevance to secretory diarrhoea. F Diarrhoeal Dis Res 1990;8:133-42.

20 Knutton S, Baldwin T, Williams PH, McNeish AS. Actin accumulation at sites of bacterial adhesion to tissue culture cells: basis of a new diagnostic test for enteropathogenic and enterohemorrhagic Escherichia coli. Infect Immun 989:57:1290-8.

21 Donnenberg MS, Calderwood SB, Donohue-Rolfe A, et al. Construction and analysis of TnphoA mutants of enteropathogenic Escherichia coli unable to invade HEp-2 cells. Infect Immun 1990;58:1565-71.

22 Collington GK, Shaw RK, Knutton S, Booth IW. Pathophysiology of enteropathogenic Escherichia coli diarrhoea: new insights using Caco-2 cells. Gut 1993;34:F224.

23 Taylor J. Infectious infantile enteritis, yesterday and today. Proceedings of the Royal Society of Medicine 1970;63:1297301.

24 Vuopio-Varkila J, Schoolnik GK. Localized adherence by enteropathogenic Escherichia coli is an inducible phenotype associated with the expression of new outer membrane proteins. 7 Exp Med 1991;174:1167-77.

25 Canil C, Rosenshine I, Ruschkowski S, et al. Enteropathogenic Escherichia coli decreases the transepithelial electrical resistance of polarized epithelial monolayers. Infect Immun 1993;61:2755-62.

26 Spitz J, Yuhan R, Koutsouris A, et al. Enteropathogenic Escherichia coli adherence to intestinal epithelial monolayers diminishes barrier function. Am f Physiol 1995;268: G375-9.

27 Grasset E, Bernabeu J, Pinto M. Epithelial properties of human colonic carcinoma cell line Caco-2: effect of secretagogues. Am f Physiol 1985;248:C140-8.

28 Grasset E, Pinto M, Dussaulx MZ, Desjeux J-F. Epithelial properties of human colonic carcinoma cell line Caco-2: electrical parameters. Am $\mathcal{F}$ Physiol 1984;247:C260-7.

29 Pinto M, Robine-Leon S, Appay M-D, et al. Enterocyte-like differentiation and polarization of the human colon carcinoma $323-30$.

30 Rousset M, Laburthe M, Pinto M, et al. Enterocytic differentiation and glucose utilization in the human colon tumour cell line Caco-2: modulation by forskolin. $f$ Cell Physiol 1985;123:377-385.

31 Blais A, Bissonnette P, Berteloot A. Common characteristics for $\mathrm{Na}^{+}$-dependent sugar transport in Caco-2 cells and human fetal colon. f Membr Biol 1987;99:113-25.

32 Hidalgo IJ, Borchardt RT. Transport of a large neutral amino acid (phenylalanine) in a human intestinal epithelial

33 Mohrmann I, Mohrmann M, Biber J, Murer H. Sodium-

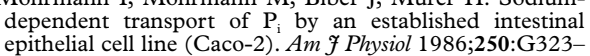
30 .

34 Stein MA, Mathers DA, Yan H, et al. Enteropathogenic Escherichia coli markedly decreases the resting membrane 
potential of Caco-2 and HeLa human epithelial cells. Infect Immun 1996;64:4820-5.

35 Bernabeu J, Pinto M, Grasset E. Properties of human colon carcinoma Caco-2 cells: response to secretagogues. Gastroenterol Clin Biol 1984;8:861-2.

36 Chang EB, Bookstein C, Vaandrager A, et al. Cystic fibrosis transmembrane regulator mRNA expression relative to ion-nutrient transport in spontaneously differentiating human intestinal Caco-2 cells. F Lab Clin Med 1991;118 $377-81$.
37 Watson AJM, Levine S, Donowitz M, Montrose MH. Kinetics and regulation of a polarized $\mathrm{Na}^{+}-\mathrm{H}^{+}$exchanger from Caco-2 cells, a human intestinal cell line. Am f Physiol 1991,261:G229-38.

38 Pappenheimer JR. Physiological regulation of transepithelial impedance in the intestinal mucosa of rats and hamsters. $\mathcal{F}$ Membr Biol 1987;100:137-48.

39 Madara JL, Pappenheimer JR. Structural basis for physiological regulation of paracellular pathways in intestinal epithelia. F Membr Biol 1987;100:149-64.

\section{Call for Patients with Familial Pancreatic Disease: The EUROPAC Register}

We are establishing a national UK register (EUROPAC) of families with hereditary pancreatitis, familial pancreatic cancer and where pancreatic cancer has occurred as part of a familial cancer syndrome. This collaboration in Liverpool is between the Department of Clinical Genetics ( Dr Ian Ellis) and the Academic Department of Surgery (Professor John Neoptolemos). The data and samples are collected by behalf of ESPAC (the European Study Group for Pancreatic Cancer), Professor Markus Büchler, Berne, and Professor Hans Beger, Ulm. The study will collaborate with Dr David Whitcomb of the Midwest Multicenter Pancreatitis study group in the United States. We aim to recruit families who are prepared to donate blood for DNA studies. We hope to gain a clearer understanding of the genetic relationship between hereditary pancreatitis and familial pancreatic cancer, and develop screening protocols for individuals at risk.

Hereditary pancreatitis is associated with a mutation in the recently identified cationic trypsinogen gene. This mutation renders the enzyme active within the pancreas, leading to autodigestion. Individuals with recurrent pancreatitis have a greatly increased risk of developing pancreatic cancer, and there is some evidence that DNA analysis of cells from pancreatic fluid may be valuable in detecting premalignant changes which can predict the development of pancreatic adenocarcinoma.

The criteria for inclusion in the study are as follows:

- Hereditary pancreatitis: Three relatives with chronic pancreatitis in the absence of ethanol dependence, hypercalcaemia, or an obstructive cause.

- Familial pancreatic cancer: Two first degree relatives with pancreatic adenocarcinoma. Three or more relatives with pancreatic ductal adenocarcinoma. Pancreatic ductal adenocarcinoma in any two relatives where the sum of their ages is less than 110 years.

- Other familial cancer syndromes: A single documented pancreatic ductal adenocarcinoma in any family with an established familial cancer syndrome-for example, BRCA2, FAMMM, A-T, HNPCC, or FAP.

If you know of any suitable families who may be interested in joining the study, please contact: Fiona McRonald, Clinical Genetics, Alder Hey Children's Hospital, Eaton Road, Liverpool L12 2AP. Tel: 01512525905.

Thank you for your help. 